\title{
Prediction of Physicochemical Properties of SARS-CoV-2 Protein in Bangladesh
}

\author{
Nilanjan Roy \\ Department of Biomedical Engineering \\ Military Institute of Science and Technology \\ Dhaka-1216, Bangladesh \\ Corresponding author: nilanjan.roy0@gmail.com
}

\begin{abstract}
Awareness of the physicochemical properties of the severe acute respiratory syndrome coronavirus 2 (SARS-CoV-2) is urgently required for the rapid production of live attenuated and inactivated vaccines. To develop subunit vaccines, it's also important to understand these properties for similar viral proteins. In this study, we predicted the physicochemical properties of SARS-CoV-2 protein that has been sequenced from Bangladeshi patients. Here we reported the number of amino acids, molecular weight, theoretical pI, amino acid composition, extinction coefficients, estimated half-life, instability index, aliphatic index, and grand average of hydropathicity of the SARS-CoV-2 protein in Bangladesh. As Bangladesh is consistently trying to contribute in the vaccine development process of SARS-CoV-2, we believe that this biocomputational study of physicochemical properties will give meaningful insights and will ease the way of vaccine development.
\end{abstract}

\section{Keywords}

SARS-CoV-2; Physicochemical properties; Peptide analysis.

\section{Introduction}

As the COVID-19 pandemic has arisen worldwide, everyone has been looking for ways to monitor the spread of the disease. Since the adaptation strategies of the virus come from its essence, scientists put a considerable effort into identifying and improving appropriate strategies for successful prevention and treatment as well as tracking its virulence, variants, and mutations. Coronaviruses (CoVs) are enveloped positive-sense RNA viruses. They are marked by club-like spikes and have an unusually large RNA genome with a special replication technique [1]. Compared with the reference Wuhan genome NC 045512.2 researchers have analyzed and annotated all SARS-CoV-2 mutations, finding an average of 7.23 mutations per sample. This result demonstrates the prevalence of single nucleotide transitions as the primary mutational form worldwide. There are at least three clades distinguished by specificity in geography and genome [2]. It is also reported by analyzing SARS-CoV-2 genomes from 68 countries that there are in total 65776 variants with 5775 distinct variants of SARS CoV-2. The 5775 distinct variants consist of 2969 missense mutations, 1965 synonymous mutations, 484 mutations in the non-coding regions, 142 noncoding deletions, 100 in-frame deletions, 66 non-coding insertions, 36 stop-gained variants, 11 frameshift deletions, and two in-frame insertions and thus it is evident that SARS-CoV-2 has distinct variants from 
country to country because of its unique replication techniques [3]. The analysis showed that in different parts of its non-structural proteins (NSPs), SARS-CoV-2 has persistently undergone major mutations [4]. So, it's an important fact that to make a proper vaccine genome sequences of SARS-CoV-2 protein should be analyzed from each country that has been affected by this virus. Bangladesh is a country where cases of COVID-19 is increasing day by day. Bangladesh's coronavirus mutation rate is higher than the global average, and the virus is rapidly evolving, according to a study by the Bangladesh Council of Scientific and Industrial Research (BCSIR). It found the world's coronavirus mutation rate at 7.23 percent while Bangladesh's rate is 12.6 percent. The outcome of the analysis was based on data on 263 genome sequencing events. A study of 263 genomes of SARS-CoV-2 showed that mutations occur at a total of 737 points including 356 substitutions of non-synonymous amino acids. To get more meaningful insights, in this study we aimed to analyze the physicochemical properties of SARS-CoV-2 protein that has been found and sequenced in Bangladesh. These properties will be valuable assets for the development of the SARS-CoV2 vaccine.

\section{Materials and Methods}

Genomic Research Lab of Bangladesh (Council of Scientific and Industrial Research) has sequenced the genome of the SARS-CoV-2 virus from Bangladeshi patients. We leveraged this genome sequence data of SARS-CoV-2 from NCBI (National Center for Biotechnology Information) [5]. After retrieving the data from NCBI, we used EMBOSS Transeq [6]. EMBOSS Transeq converts nucleic acid sequences into peptide sequences that correspond to them. The three forward and three reverse frames can be interpreted and several frame translations can be performed at once. Thus, we predicted the peptide sequence of our sample SARS-CoV-2 protein by this method. Then ProtParam was used to predict the physicochemical properties of SARS-CoV-2 protein [7]. ProtParam is a system that allows different physical and chemical parameters for a given protein to be computed. The measured parameters include molecular weight, theoretical pI, the composition of amino acids, atomic composition, extinction coefficient, approximate half-life, instability index, aliphatic index, and high hydropathicity average.

\section{Result}

After running the analysis, we found that the number of amino acids is 9193 in SARS-CoV-2 protein that has been sequenced in Bangladesh. The molecular weight seemed to be 1069547.70 and the theoretical pI is 9.02. Note that the isoelectric point $(\mathrm{pI})$ is the value at which a macromolecular polyprotic species has a total net surface charge equal to zero. Protein $\mathrm{pI}$ values are among the quantities most commonly determined and recorded in both biochemistry and proteomics [8]. The composition of the amino acid of the SARS$\mathrm{CoV}-2$ protein was also determined.

Table: Amino acid composition of SARS-CoV-2 protein

\begin{tabular}{|l|l|l|l|}
\hline Amino acid & $\begin{array}{l}\text { Information } \\
\text { (Source: https://www.wikipedia.org/) }\end{array}$ & $\begin{array}{l}\text { Numbers } \\
\text { of Amino } \\
\text { Acids }\end{array}$ & Composition \\
\hline Ala (A) & $\begin{array}{l}\text { Alanine is an } \alpha \text {-amino acid that is used in the } \\
\text { biosynthesis of proteins. It contains an amine } \\
\text { group and a carboxylic acid group, both attached } \\
\text { to the central carbon atom which also carries a } \\
\text { methyl group side chain. }\end{array}$ & 475 \\
\hline
\end{tabular}




\begin{tabular}{|c|c|c|c|}
\hline $\operatorname{Arg}(\mathrm{R})$ & $\begin{array}{l}\text { Arginine, an essential amino acid, has a positively } \\
\text { charged guanidino group. Arginine is well } \\
\text { designed to bind the phosphate anion and is often } \\
\text { found in the active centers of proteins that bind } \\
\text { phosphorylated substrates. }\end{array}$ & 558 & $6.1 \%$ \\
\hline $\operatorname{Asn}(\mathrm{N})$ & $\begin{array}{l}\text { Asparagine is an } \alpha \text {-amino acid that is used in the } \\
\text { biosynthesis of proteins. It contains an } \alpha \text {-amino } \\
\text { group, an } \alpha \text {-carboxylic acid group, and a side } \\
\text { chain carboxamide, classifying it as a polar, } \\
\text { aliphatic amino acid. It is non-essential in } \\
\text { humans, meaning the body can synthesize it. }\end{array}$ & 471 & $5.1 \%$ \\
\hline Asp (D) & $\begin{array}{l}\text { Aspartic acid is an } \alpha \text {-amino acid that is used in the } \\
\text { biosynthesis of proteins. Like all other amino } \\
\text { acids, it contains an amino group and a carboxylic } \\
\text { acid. }\end{array}$ & 290 & $3.2 \%$ \\
\hline Cys (C) & $\begin{array}{l}\text { Cystatin C or cystatin } 3 \text { a protein encoded by the } \\
\text { CST3 gene, is mainly used as a biomarker of } \\
\text { kidney function. }\end{array}$ & 636 & $6.9 \%$ \\
\hline Gln (Q) & $\begin{array}{l}\text { Glutamine is an } \alpha \text {-amino acid that is used in the } \\
\text { biosynthesis of proteins. Its side chain is similar } \\
\text { to that of glutamic acid, except the carboxylic acid } \\
\text { group is replaced by an amide. It is classified as a } \\
\text { charge-neutral, polar amino acid. }\end{array}$ & 325 & $3.5 \%$ \\
\hline Glu (E) & $\begin{array}{l}\text { Glutamic acid is an } \alpha \text {-amino acid that is used by } \\
\text { almost all living beings in the biosynthesis of } \\
\text { proteins. It is non-essential in humans, meaning } \\
\text { the body can synthesize it. It is also an excitatory } \\
\text { neurotransmitter, in fact, the most abundant one, } \\
\text { in the vertebrate nervous system. }\end{array}$ & 270 & $2.9 \%$ \\
\hline Gly (G) & $\begin{array}{l}\text { Glycine is an amino acid that has a single } \\
\text { hydrogen atom as its side chain. It is the simplest } \\
\text { amino acid, with the chemical formula } \mathrm{NH}_{2}-\mathrm{CH}_{2}- \\
\text { COOH. Glycine is one of the proteinogenic amino } \\
\text { acids. It is encoded by all the codons starting with } \\
\text { GG. }\end{array}$ & 392 & $4.3 \%$ \\
\hline His $(\mathrm{H})$ & $\begin{array}{l}\text { Histidine is an } \alpha \text {-amino acid that is used in the } \\
\text { biosynthesis of proteins. It contains an } \alpha \text {-amino } \\
\text { group, a carboxylic acid group, and an imidazole } \\
\text { side chain, classifying it as a positively charged } \\
\text { amino acid at physiological pH. }\end{array}$ & 331 & $3.6 \%$ \\
\hline Ile (I) & $\begin{array}{l}\text { Isoleucine is an } \alpha \text {-amino acid that is used in the } \\
\text { biosynthesis of proteins. It contains an } \alpha \text {-amino } \\
\text { group, an } \alpha \text {-carboxylic acid group, and a } \\
\text { hydrocarbon side chain with a branch. It is } \\
\text { classified as a non-polar, uncharged, branched- } \\
\text { chain, aliphatic amino acid. }\end{array}$ & 438 & $4.8 \%$ \\
\hline
\end{tabular}




\begin{tabular}{|c|c|c|c|}
\hline Leu (L) & $\begin{array}{l}\text { Leucine is an essential amino acid that is used in } \\
\text { the biosynthesis of proteins. Leucine is an } \alpha \text { - } \\
\text { amino acid, meaning it contains an } \alpha \text {-amino } \\
\text { group, an } \alpha \text {-carboxylic acid group, and a side } \\
\text { chain isobutyl group, making it a non-polar } \\
\text { aliphatic amino acid. }\end{array}$ & 887 & $9.6 \%$ \\
\hline Lys (K) & $\begin{array}{l}\text { Lysine is an } \alpha \text {-amino acid that is used in the } \\
\text { biosynthesis of proteins. It contains an } \alpha \text {-amino } \\
\text { group, an } \alpha \text {-carboxylic acid group, and a side } \\
\text { chain lysyl, classifying it as a basic, charged, } \\
\text { aliphatic amino acid. It is encoded by the codons } \\
\text { AAA and AAG. }\end{array}$ & 413 & $4.5 \%$ \\
\hline Met (M) & $\begin{array}{l}\text { Methionine is an } \alpha \text {-amino acid that is used in the } \\
\text { biosynthesis of proteins. It contains an } \alpha \text {-amino } \\
\text { group (which is in the protonated -NH3+ form } \\
\text { under biological conditions), a carboxyl group } \\
\text { (which is in the deprotonated - COO- form under } \\
\text { biological conditions), and an S-methyl thioether } \\
\text { side chain, classifying it as a nonpolar, aliphatic } \\
\text { amino acid. }\end{array}$ & 117 & $1.3 \%$ \\
\hline Phe (F) & $\begin{array}{l}\text { Phenylalanine is an essential } \alpha \text {-amino acid with } \\
\text { the formula } \mathrm{C}_{9} \mathrm{H}_{11} \mathrm{NO}_{2} \text {. It can be viewed as a } \\
\text { benzyl group substituted for the methyl group of } \\
\text { alanine, or a phenyl group in place of terminal } \\
\text { hydrogen of alanine. }\end{array}$ & 593 & $6.5 \%$ \\
\hline Pro $(\mathrm{P})$ & $\begin{array}{l}\text { Proline (symbol Pro or } \mathrm{P} \text { ) is a proteinogenic } \\
\text { amino acid that is used in the biosynthesis of } \\
\text { proteins. It is non-essential in humans, meaning } \\
\text { the body can synthesize it from the non-essential } \\
\text { amino acid L-glutamate. It is encoded by all the } \\
\text { codons starting with CC (CCU, CCC, CCA, and } \\
\text { CCG). }\end{array}$ & 290 & $3.2 \%$ \\
\hline $\operatorname{Ser}(S)$ & $\begin{array}{l}\text { Serine is important in metabolism in that it } \\
\text { participates in the biosynthesis of purines and } \\
\text { pyrimidines. It is the precursor to several amino } \\
\text { acids including glycine and cysteine, as well as } \\
\text { tryptophan in bacteria. }\end{array}$ & 811 & $8.8 \%$ \\
\hline Thr (T) & $\begin{array}{l}\text { Threonine is an amino acid that is used in the } \\
\text { biosynthesis of proteins. It contains an } \alpha \text {-amino } \\
\text { group, a carboxyl group, and a side chain } \\
\text { containing a hydroxyl group, making it a polar, } \\
\text { uncharged amino acid. It is essential in humans, } \\
\text { meaning the body cannot synthesize it: it must be } \\
\text { obtained from the diet. }\end{array}$ & 679 & $7.4 \%$ \\
\hline
\end{tabular}




\begin{tabular}{|c|c|c|c|}
\hline $\operatorname{Trp}(\mathrm{W})$ & $\begin{array}{l}\text { Tryptophan is an } \alpha \text {-amino acid that is used in the } \\
\text { biosynthesis of proteins. Tryptophan contains an } \\
\alpha \text {-amino group, an } \alpha \text {-carboxylic acid group, and a } \\
\text { side chain indole, making it a non-polar aromatic } \\
\text { amino acid. It is essential in humans, meaning that } \\
\text { the body cannot synthesize it and it must be } \\
\text { obtained from the diet. }\end{array}$ & 263 & $2.9 \%$ \\
\hline Tyr (Y) & $\begin{array}{l}\text { Tyrosine or 4-hydroxyphenylalanine is one of the } \\
20 \text { standard amino acids that are used by cells to } \\
\text { synthesize proteins. It is a non-essential amino } \\
\text { acid with a polar side group. }\end{array}$ & 505 & $5.5 \%$ \\
\hline Val (V) & $\begin{array}{l}\text { Valine (symbol Val or V is an } \alpha \text {-amino acid that } \\
\text { is used in the biosynthesis of proteins. It contains } \\
\text { an } \alpha \text {-amino group (which is in the protonated } \\
-\mathrm{NH} 3+\text { form under biological conditions), an } \alpha- \\
\text { carboxylic acid group (which is in the } \\
\text { deprotonated -COO- form under biological } \\
\text { conditions), and a side chain isopropyl group, } \\
\text { making it a non-polar aliphatic amino acid. }\end{array}$ & 548 & $6.0 \%$ \\
\hline Pyl (O) & $\begin{array}{l}\text { Pyrrolysine is an } \alpha \text {-amino acid that is used in the } \\
\text { biosynthesis of proteins in some methanogenic } \\
\text { archaea and bacteria; it is not present in humans. } \\
\text { It contains an } \alpha \text {-amino group, a carboxylic acid } \\
\text { group. Its pyrroline side-chain is similar to that of } \\
\text { lysine in being basic and positively charged at } \\
\text { neutral pH. }\end{array}$ & 0 & $0.0 \%$ \\
\hline $\operatorname{Sec}(\mathrm{U})$ & $\begin{array}{l}\text { Selenocysteine is the } 21 \text { st proteinogenic amino } \\
\text { acid. Selenocysteine exists naturally in all three } \\
\text { domains of life, but not in every lineage, as a } \\
\text { building block of selenoproteins. Selenocysteine } \\
\text { is a cysteine analogue with a selenium-containing } \\
\text { selenol group in place of the sulfur-containing } \\
\text { thiol group. }\end{array}$ & 0 & $0.0 \%$ \\
\hline
\end{tabular}

Our analysis predicts that the total number of negatively charged residues (Asp + Glu) is 560 and the total number of positively charged residues (Arg + Lys) is 971 in SARS-CoV-2 protein that is detected in Bangladesh.

\section{Extinction coefficients:}

The Coefficient of Extinction applies to many different measurements of light absorption in a medium. Extinction coefficients are in units of $\mathrm{M}^{-1} \mathrm{~cm}^{-1}$, at $280 \mathrm{~nm}$ measured in water [9]. In SARS-CoV-2 protein Ext. coefficient is 2238700 when Abs $0.1 \%(=1 \mathrm{~g} / \mathrm{l})$ is 2.093, assuming all pairs of Cys residues form cystines. Again, Ext. coefficient is 2198950 of SARS-CoV-2 protein when Abs 0.1\% (=1 g/l) is 2.056, assuming all Cys residues are reduced.

\section{Estimated half-life:}

The $\mathrm{N}$-end law, and therefore the N-terminal amino acid, simply specify the protein's half-life. The assumed half-life of proteins has been investigated in mammals, yeast, and E. coli [10]. The N-terminal of the sequence considered is I (Ile). The estimated half-life is 20 hours (mammalian reticulocytes, in vitro), 30 min (yeast, in vivo), and $>10$ hours (Escherichia coli, in vivo). 


\section{Instability index:}

A protein whose index of instability is less than 40 is predicted as stable, a value greater than 40 predicts that the protein may be unstable. The protein's aliphatic index is known as the relative volume of the aliphatic side chains (alanine, valine, isoleucine, and leucine) occupied [11]. The instability index (II) is computed to be 44.01 . This classifies the protein as unstable.

\section{Aliphatic index:}

The protein's aliphatic index is known as the relative volume of the aliphatic side chains (alanine, valine, isoleucine, and leucine) occupied. It can be considered a beneficial factor in improving globular protein thermostability [12]. The aliphatic index of SARS-CoV-2 protein is found to be 77.58.

\section{Grand average of hydropathicity (GRAVY):}

The Grand Average Index of Hydropathicity (GRAVY) is used to reflect the peptide hydrophobicity value, which measures the sum of all amino acid hydropathy values divided by the length of the sequence [13]. -0.084 is found as the Grand average of hydropathicity (GRAVY) of SARS-CoV-2 protein.

\section{Conclusion}

In characterizing the current coronavirus and developing its vaccine, scientists have made progress, but there are still several questions to be addressed. COVID-19 is a major biological hazard and is a concern globally. In the latency span, COVID-19 is highly contagious. To promote awareness and to enable faster data dissemination and analysis in accordance with the principles of precision bioinformatics is needed now more than ever. It may be important to implement and invest in more modern technologies to investigate the physicochemical properties of SARS-CoV-2 protein. Any mutation that occurs in the SARS-CoV-2 protein would be highly important and for studying these mutations we need to be aware of their physicochemical properties. Physicochemical properties help to find strategies for developing a vaccine and determining the quality of vaccine products. This study predicts the physicochemical properties of SARS-CoV-2 protein in Bangladesh. As it has been already reported that Bangladesh is trying to develop a vaccine for this deadly virus on their own, we are confident that our reports of these physicochemical properties will greatly benefit the progress of this vaccine development.

\section{References}

1. Fehr, A. and Perlman, S., 2015. Coronaviruses: An Overview of Their Replication and Pathogenesis. Coronaviruses, pp.1-23.

2. Mercatelli, D. and Giorgi, F., 2020. Geographic and Genomic Distribution of SARS-CoV-2 Mutations. Frontiers in Microbiology, 11.

3. Koyama, T., Platt, D. and Parida, L., 2020. Variant Analysis Of SARS-Cov-2 Genomes.

4. Abdullahi, I., Emeribe, A., Ajayi, O., Oderinde, B., Amadu, D. and Osuji, A., 2020. Implications of SARS-CoV-2 genetic diversity and mutations on pathogenicity of the COVID-19 and biomedical interventions. Journal of Taibah University Medical Sciences, 15(4), pp.258-264.

5. National Center for Biotechnology Information (NCBI) [Internet]. Bethesda (MD): National Library of Medicine (US), National Center for Biotechnology Information; [1988] - [cited 2020 Sep 18]. Available from: https://www.ncbi.nlm.nih.gov/

6. Madeira, F., Park, Y., Lee, J., Buso, N., Gur, T., Madhusoodanan, N., Basutkar, P., Tivey, A., Potter, S., Finn, R. and Lopez, R., 2020. The EMBL-EBI Search And Sequence Analysis Tools Apis In 2019. 
7. Gasteiger E., Hoogland C., Gattiker A., Duvaud S., Wilkins M.R., Appel R.D., Bairoch A.; Protein Identification and Analysis Tools on the ExPASy Server; (In) John M. Walker (ed): The Proteomics Protocols Handbook, Humana Press (2005). pp. 571-607.

8. Audain, E., Ramos, Y., Hermjakob, H., Flower, D. and Perez-Riverol, Y., 2015. Accurate estimation of isoelectric point of protein and peptide based on amino acid sequences. Bioinformatics, 32(6), pp.821-827.

9. Gill, S. and von Hippel, P., 1989. Calculation of protein extinction coefficients from amino acid sequence data. Analytical Biochemistry, 182(2), pp.319-326.

10. Segal, H., Matsuzawa, T., Haider, M. and Abraham, G., 1969. What determines the half-life of proteins in, vivo? Some experiences with alanine aminotransferase of rat tissues. Biochemical and Biophysical Research Communications, 36(5), pp.764-770.

11. Gamage, D., Gunaratne, A., Periyannan, G. and Russell, T., 2019. Applicability of Instability Index for In vitro Protein Stability Prediction. Protein \& Peptide Letters, 26(5), pp.339-347.

12. Shannahan, J., Lai, X., Ke, P., Podila, R., Brown, J. and Witzmann, F., 2013. Silver Nanoparticle Protein Corona Composition in Cell Culture Media. PLoS ONE, 8(9), p.e74001.

13. Chang, K. and Yang, J., 2013. Analysis and Prediction of Highly Effective Antiviral Peptides Based on Random Forests. PLoS ONE, 8(8), p.e70166. 